\title{
DOG SACRIFICE IN ANCIENT AND MODERN GREECE: FROM THE SACRIFICE RITUAL TO DOG TORTURE (KYNOMARTYRION)
}

\author{
Manolis G. Sergis
}

\begin{abstract}
The article presents and discusses the custom of kynomartyrion (dog torture) which took place in the Greek lands until the 1980s. In many areas it stopped in the 1930s because of its cruelty. The author begins his discussion with the presentation of some elements that are related to the dog. More specifically, the dog is an animal that entered the humanized environment long ago and belongs to the creatures whose nature is twofold because it is part of the human and the non-human worlds and it has been treated as twofold by at least the Indo-Europeans. It is also maintained that the liminal Hellenistic period was decisive for the formation of folk worship because of the religious syncretism and the invasion of demons that dominated in the Eastern Mediterranean. The author points out its remarkable similarities to ancient Greek and Roman (and Indo-European) fertile, cathartic and other sacrificial practices. Due to industrialization of agriculture and rationalization of the magical way of thought of the "traditional" peasant, performance of the custom was transformed into a folkloric, spectacular one with intensely violent and sadistic behaviour on the part of humans in the places where it still took place after 1960. The writer argues that violence was always an inherent characteristic of the custom. Nonetheless, the archaic, and later folk thinking ritualized the performance and attributed to it a different facet, devoid of any sacred elements, during the 20th century where its inherent violence was manifested in its raw essence.
\end{abstract}

Key words: Artemis (Diana), Augurium Canarium, cathartic rituals, dogs, dog sacrifice, fertility rituals, folklorism, Greece, Hecate, kynomartyrion (dog torture), Lupercalia, performance, religious syncretism, Robigalia

\section{INTRODUCTION}

This study presents and discusses the custom of kynomartyrion (dog torture) which took place in many regions of Greek lands until the end of the 1970s. In most areas, however, it had faded away as early as the 1930s. In all its five forms, as will be analyzed below, it can be considered almost Pan-Hellenic, since its distribution shows that it was perform everywhere apart from the Ionian Islands, Cyclades and Crete. In particular, we have records of this cus- 
tom from many villages and towns of the Peloponnese, Attica, Thessaly, Epirus, Macedonia, Western Thrace, Samos, Asia Minor and Eastern Thrace (Puchner 1977: 151), the last two regions being part of Turkish territory nowadays. Its presence in Thessaly is certainly due to the settlement in the early 20th century of Greek refugees from various parts of Eastern Romylia (Sachinidis 1994: 83ff). It can be seen from the geographical distribution of this custom, with its peculiar sacrificial behaviour, that it was part of the culture in areas where the Greek element was dominant, in Eastern Romylia, Thrace and Asia Minor, whence it spread to the rest of Greek lands. It was preserved in Bulgaria (Vakarelski 1969: 320), in Eastern Romylia (after Bulgarian occupation in 1885) and in Turkey (Puchner 1989: 48). The close contact between Samos (Stamatiadis 1891: 366-367), Dodecannese and Asia Minor facilitated its spread to these islands as well.

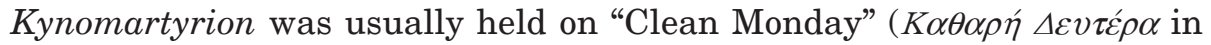
Greek and Ćisti ponedélnik in Bulgarian), the first day of the Lent (forty days before Easter). The day was also called Skylodeftera (Dog Monday) and Drabalodeftera (Monday of Seesaw) in Samos. It was held on meat-eating Monday in many places of Thrace (Kourtidis 1938-39: 93) but also on Cheese-Eating Sunday in Lykoudi of Thessaly (Puchner 1977: 151).

Its form was quite typified: on top of two wooden poles a rope (6-7 meters long) was fixed. This rope was double and twisted so as to leave only a loop to take the dog's head. When this had been done, the lower part of the poles was taken away and the rope started unwinding at great speed and the dog was launched into the air. In other places the dog was whirled around in the air, but was not launched, a fact which caused the dog to bark dreadfully before it died (Puchner 1977: 151; 1989: 48). In Maganiako, the rope was tied to two plane trees. In Aspropyrgos (of Attica) the ropes were decorated with flowers. In Lykoudi, two five-metre high poles were used, to the top of which two ropes were tied and held steadily on the ground by two men, one on the left and one on the right. At the bottom of the poles a rope with a piece of wood (3-4 meters long) was fixed, which had a round opening for the dog to be placed in. In Reisdere of Izmir (Smyrni) in Turkey, the kynomartyrion (leading to the death of the animal) took place on the inhabitants' return from the seashore where they had collected sea food. In Mouzaki of Thessaly, people hanged the dogs from the Karambali Bridge.

A more detailed description of the ceremony is reported by Athanassios Papatriantaphyllou from the village Roditis in Komotini (Western Thrace). To this description, on "Clean Monday" at noon, a crowd of local and foreign people gathered in the central square of the village to watch the dog hanging. 
Dancing to the accompaniment of bagpipes played by a musician who arrived with his friends had preceded the hanging. In another corner of the square, the kynomartyrion contraption had already been set up and fixed. The dancers stopped their dance to watch the spectacle. The two ropes were twisted and the dog was fixed in this wooden constrictor very tightly. When the two ropes were pulled, the dog started whirling around in the air as far as a distance of four metres. The victims, instead of being killed, fell on the ground very violently, dizzy and wild with fear, fiercely attacking their owners (Papatriantaphyllou 1993: 204). This is to be seen as either a more humane evolution of the custom or the emphasis here is put on the dog's howling, another conception involved in the custom as discussed later in this study. A similar ritual dance (before the kynomartyrion) took place in the villages Mikro and Megalo Bogialike

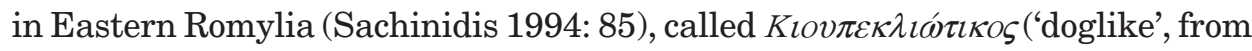
the village Kı৩л $\varepsilon \kappa \lambda i$, which takes its name from the Turkish word kiopek = dog). The presence of dance is justified as a vital subordinate celebration, which helped forward the whole ceremony. This dromena, with its local varieties, was watched by spectators in high spirits and it could last up to three hours (e.g. in Maganiako). It is not accidental that, due to the festive atmosphere created by the ceremony, it was also called the "Dog Feast" (Megas 1956: 119; Vakarelski 1969: 321). In the area of Xanthi, a special committee judged "if the dog was successfully twisting around".

Apart from this standard form of the custom, four other variations of kynomartyrion can be distinguished:

1. Spitting ( $\sigma \circ \hat{v} \beta \lambda \iota \sigma \mu \alpha)$ : in Soufli, according to some informants (not, however, cross-checked by the folklorist G. Megas) dogs were spitted (and died), instead of being hanged (Papatriantaphyllou 1993: 203).

2. Drowning: the dogs' heads, in this case (in Petra of Preveza), were placed in a loop, whirled around and thrown in the water to drown.

3. Stoning: (in Rhodes) on "Clean Monday" children chased and stoned dogs. This custom was reported until the 1930s (Vrodis 1934-37: 587). It has been recorded in Bulgaria in this form. Empty boxes were tied to the dog's tails and stones and pieces of wood were thrown at the terrified animals as they ran around (Vakarelski 1969: 321).

4. Ridiculing: tins would be tied to the dogs' tails (in Peloponnese, in Lesvos and in Evros in Western Thrace) to make fun of the whole event.

Having described the custom under discussion in this study, the following first part of this article discusses the evolutionist development of the custom as a survival of ancient rituals (from the ancient times until the mid 20 th century). 
Remarkable similarities to ancient Greek and Roman (and Indo-European) fertile, cathartic and other sacrificial practices are revealed. On the basis of this discussion, the second part focuses on the different functions (fertility, cathartic, etc.) of the Modern Greek custom and ends with the changes that the custom underwent after the 1960s when it was transformed into an entertaining performance, having, thus, lost its previous meaning and function.

\section{THE EVOLUTIONIST DEVELOPMENT OF THE CUSTOM AS A SURVIVAL OF AN ANCIENT RITUAL (FROM THE ANCIENT TIMES UNTIL THE MID 20THCENTURY)}

This section begins with the presentation of some elements that are related to the dog and have mainly to do with its twofold nature within the Indo-Europeans. It is also maintained that the liminal Hellenistic period was decisive for the formation of the folk worship because of religious syncretism and the invasion of demons that dominated in Eastern Mediterranean. It was mainly during this period that the dog was related to magic. The section ends with a presentation of dog sacrifices in ancient Greece and Rome revealing remarkable similarities of the custom under discussion to ancient Greek and Roman (and Indo-European) fertile, cathartic and other sacrificial practices.

\section{The twofold nature of the dog from the ancient times until nowadays}

The dog, ever since it was tamed and introduced to the human environment as a pet, has been transformed into an interstitial creature, moving easily between the world of the human and the non-human in most places of the world (Crockford 2002). In this sense, it was to be regarded neither as a person nor as an animal (Franco 2003: 91-93). However, because of the human behaviour with regard to the dog (referred to later in this work), the dog was capable of assuming the roles both of an animal of high status and a person of low status. The dog was appreciated for being a carnivorous mammal that had been adapted to existence alongside man, being itself partly humanized. At the same time, nonetheless, the dog was distinguished by a mixture of remarkable and loathsome characteristics. This ambiguity marks almost all the cultural conceptions of the animal in the literature of the Medieval West. A similar to the above ambiguity appears in French medieval literary texts as well (Ramm 2005: 47-69). 
In the ancient Greek and Roman context, the dog, as an ancient chthonic deity and symbol of death (Toynbee 1973: 102-124), belonged to the group of animals sacrificed to the associated to death deities (Scholz 1937). Evidence of its chthonic nature has been documented frequently in Modern Greek $\Lambda \alpha O$ -

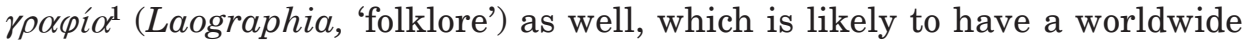
application. More specifically, due to its chthonic nature, the dog was assumed to belong to both worlds, the underworld, the magic sphere of dreams (Drexl 1923: 435, 439, 444; Drexl 1925: 358, 360) and omens (Burriss 1935: 35-37) and the upper world. In particular, its howling was considered a precursor of death (Burriss 1935: 41) and all impending evil or disaster (Loukopoulos 1938-48: 2; Sergis 2007: 264-265), e.g. an earthquake (Papadopoulos 1951: 179). It was firmly believed that its interstitial and ambiguous status had endowed the dog with supernatural powers, for it was assigned the role to be the bearer of souls of the dead on their voyage to the underworld.

It therefore belonged to the group of creatures whose nature was twofold, exactly like the deities Hecate and Artemis (Diana), who were the closest to the dog. These deities (see the analytical reference to them later in this piece) were active at the edge of both the upper and the underworld. It is exactly this nature of the dog which justifies, as we argue in what follows, the human corresponding diachronic twofold attitude towards the animal, which has been somewhat surprisingly regarded as inexplicable by researchers. Since early times (we provide some indicative examples), the dog has been regarded a symbol of devotion, loyalty and patience (Xioutas 1978: 128ff), a protector of valuable herds (Oikonomidis 1959: 181ff), homes and hunting (Merlen 1971: $25 \mathrm{ff}$ ), it was allowed indoors, as is depicted in some iconic representations. It was sacrificed to escort and serve its master in the underworld. It was actually sometimes buried with him as with some of the dead person's relatives or servants (Franco 2003: 139-143). The ancient Athenians passed laws for its protection as the dog could not defend itself. Its master arranged burial because it had been his precious helpmate. A plethora of evidence from Greek lands, consisting of place names and adverbs (Xioutas 1978: 124-137) supports all this. ${ }^{2}$ In the Middle Ages, evidence for the owner's love for their dogs is

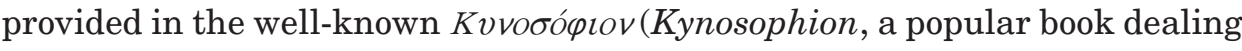
with the breeding, training and protection from illnesses of dogs) written by Demetrios Pepagomenos (see Hierakosophion: 1612). Dogs, being animals of great physical strength and endurance, offered considerable assistance to military expeditions as well. The Byzantine Rural Law imposes heavy punishments for those guilty of poisoning dogs (Oxford Dictionary of Byzantium 1991: at entry 'Dogs'). 
On the other hand, apart from positive references to the dog there have also been negative ones since Homer (see Mainoldi 1984: 113-126). The bitch, in particular, refers mainly to women or goddesses disdainfully, implying shameless, impudent, erotic conduct. The beautiful Helen, for instance, calls herself a bitch in Iliad (rhapsody Z, verse 344 (see Allen 1931) in exactly the same manner as a prostitute is called in Modern Greek and English-American. In the same epic, Zeus (Jupiter), addressing Hera (Juno), uses the same name (rhapsody $\Theta$, verse 483), which, in her turn, Hera uses for Artemis (Diana) (see $\Phi, 481$ ). Helen uses the same name for herself again in Odyssey, rhapsody $\delta$, verse 145 (see Homeri Odyssea 1889). The dog was forbidden entrance to sacred places (Mainoldi 1984: 51-52; Parker 1983: 357), since it was considered polluted..$^{3}$ It also occupied the lowest position in the sacrifice system because, as has been noted by scholars (Parker 1983: 357-358), ${ }^{4}$ it was offered to liminal gods (e.g. Eileithyia, dishonoured Mars or impure Hecate). Nonetheless, these negative characteristics were not attributed to the dogs of Asclepius at Epidaurus (Merlen 1971: 110; Gilhus 2006: 93, 109) or to the dogs that guarded temples.

\section{Hellenistic years: the period of "transition" and religious syncretism - from gods to demons}

The negative attitude towards the dog was reinforced in the 4 th century BC, when the "invasion of the demons" as interstitial deities, took place between the divine and the secular world. These were considered both to reinforce the coherence of the Universe (Plato, Symposium, 202e-203a, in Burnet: 1902) and to be bearers of the idea that through them magic could be worked. Plato, Orpheus and Pythagoras' followers accepted these popular theories and tried to justify them (Cumont 1949: 88). The priests now on, employing magical hymns and prayers used for the appeasement of some spirits, expel the ghosts of the vicious, the prematurely or violently deceased and the unburied dead, that is all Hecate's followers. These frightening images, originating from Asia Minor, and enriched with imagery from other areas, were widely accepted and passed untouched to medieval and contemporary Greek times (Godwin 1981: 66-67).

During the 4th century $\mathrm{BC}$ foreign religions, along with their ritual practices, entered the wider Greek world and led to a remarkable religious syncretism. This was due, apart from the human desire to meet the unknown, to the more humane character of the foreign deities. Magical practices, worship and mystical rituals, endeavours with astrology, constitute the elements of a continually spread folk worship, with demons as their central features. 
During the Hellenistic era the transformation of urban religion was complete. Magic was gradually connected to superstition, mystic religions and worship of demons. Black magic in the period of the Roman Empire surpasses the imagination (Nouveau-Piobb 1961: 179-221; Green 1990: 598; Johnston 1990: 143-148). Views regarding the interstitial race of the demons now constitute a common religious conception. Asclepius had beaten Hippocrates completely; the gods of the past and of the upper classes gradually lost their divine essence. The dichotomy of gods-demons was firmly established in the consciousness of people. This confusion between the old religious behaviour and the new one is discussed by Lucanus (De bello civili, book 6) and Plutarch (1947: Sur la dispatition des oracles: ch. 10, 415 a-c).

This religious unification ended up with Hecate and Artemis (Diana), the dog and the moon, being identical. As will be mentioned later, the pale light of the moon, the shadows created at night, the evocative background of terror with the dogs escorting her, constituted all the characteristics that linked Hecate with magic and chthonic powers. Hecate turned into a popular folk deity during the Hellenistic era (Decharme 1959: 156) and in the 3rd century she is often mentioned in Greek literature (Geffcken 1978: 58). It is said that the dogs could foresee her coming and this is how she was assigned the name

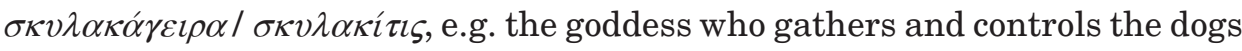
(Petropoulos 1959: 43). Under moonlight and accompanied by the howling of dogs, witches offered their magical spells or called the dead to the upper world, bound people with love ties, and drew the moon down to the earth, as Theocritus reports and as is still believed in Greece even nowadays (Petropoulos 1959: 42). All this formed the initial material whereby dogs became linked to magic and spirits, which modern Greeks believed could be suspended by the dog's howling during kynomartyrion on which the present study is focused.

This link was created during this liminal period previously described. It was at that time when the dog was associated with the expulsion of demons or their call (Politis 1904: 1310-1314; Politis 1874: 459) and was identified with ghosts (e.g. in a miracle by Holy Mary, the wicked spirit emerges "in the form of a black dog" (Kougeas 1911-12: 298-299). The plague, according to Greek tradition, is guided by dog's barking and the cock's crow during its nocturnal wanderings (Megas 1923: 487). During this period, every human disease is transferred to the body of the animal upon contact, since the dog is functioning as a scapegoat. Every part of its body, especially its sexual organs, its fat (Koukoules 1928: 461), even its body liquids (e.g. blood, urine, saliva, etc.) were extensively used in magic and magical practice (Mainoldi 1984: 169-175; Sergis 2007: 43-44, passim). Furthermore, consumption of dog flesh involved no dan- 
ger. Instead, this practice was usual, as reported in many ancient texts (see Parker 1983: 357; Gilhus 2006: 30; Mainoldi 1984: 169-175). Dog flesh was believed to relieve one from high temperature and strengthen the persons who tasted it (Gilhus 2006: 30). Until the 1960s, one protection from harm

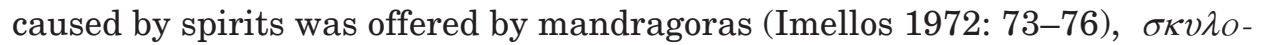
$\kappa \rho o ́ \mu \mu v \delta o$ ('onion of the dog'), magic by analogy, according to the name). The dog's gall was used for eye-illnesses, its liver (the bitten person ate its roasted liver, according to Dioskorides' magic healing principle “o $\tau \rho \omega ́ \sigma \alpha \varsigma \kappa \alpha \imath \imath \alpha ́ \sigma \varepsilon \tau \alpha \imath$ ”, e.g. "the one who hurt you will cure you" (Imellos 1972: 72ff), its teeth (Burriss 1935: 33), etc. There are dozens of exorcism rituals against dogs (see periodical Laographia, Vol. 3, 1911-12: 299) and superstitions that show the negative associations of the dog in Modern Greek consciousness. We are faced with an ambiguity once more, however, since the dog was equally associated with the birth of human beings and their healing (Gourévitch 1968: 247-281). Just like both its beloved goddesses, the dog was closely related to magical medicine and its great healer Asclepius (Toynbee 1973: 123), with whom it was depicted in many works of art. ${ }^{5}$

In modern Greece, the dog has retained many of these twofold characteristics. It is considered, for instance, humans' loyal companion - "People have never been betrayed by the dog's tail" (Oikonomidis 1959: 156, 181; Oikonomidis 1960: 82-83); it is associated with people's personal life. There is the belief that when the dog's master dies, the dog mourns exactly as if it were a human and member of the owner's family (Lianidis 1964: 160; Alexiadis 1931: 213). There are also dozens of folk traditions and narrations in which the lost master is found by his dog (Koukoules, 1948-55). The Greek language, ancient and modern, as an indisputable source of cultural history, testifies to this diachronic

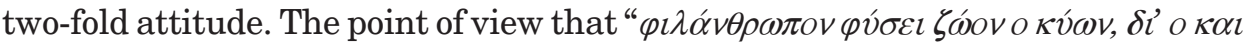

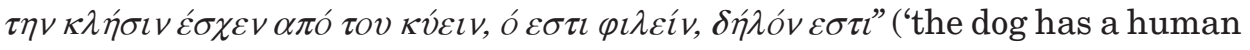
friendly nature as its name, originating from $\kappa v \varepsilon \imath v$ which means 'to love') is quite clearly demonstrated by the richness of Greek lexis and phrases relating to dogs (see Koukoules 1955: 315). Kvvé $\omega$, for instance, means embrace, kiss, pay homage (one recalls Ulysses' dog Argos or the dog of Pericles' father). Against this, however, dozens of negatively loaded words have been juxtaposed;

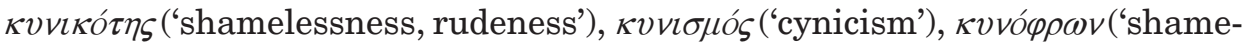
less, rude'), $\kappa v v o \beta \lambda \omega ́ \varphi$ ('a person with a shameless gaze'), кv lessly'), $\sigma \kappa v \lambda \imath \alpha ́ \zeta \omega$ ('get furious'), $\sigma \kappa v \lambda o \beta \rho i \zeta \omega$ ( in the medieval period, to 'call someone by vulgar names'), $\sigma \kappa v \lambda о \kappa \alpha \beta \gamma \alpha ́ \varsigma$ ('terrible fight'), $\sigma \kappa v \lambda о \tau \rho \omega ́ \gamma о \mu \alpha \iota$ ('fight with each other'), $\sigma \kappa v \lambda \circ \lambda o ́$ ('people who speak loudly and behave in a vulgar

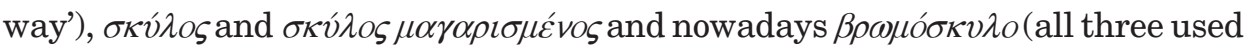
to mean 'to insult a person'). In addition to these (Koukoules 1949: 294, 299, 


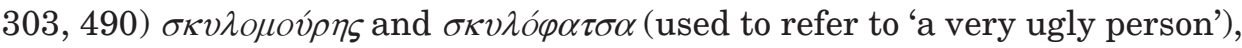

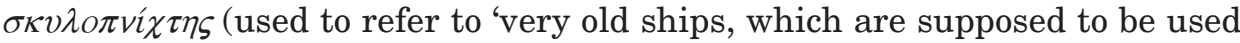
only to drown dogs', as in older days), $\sigma \kappa v \lambda \alpha ́$ ('a singer working in night entertainment places of very low quality', called $\sigma \kappa v \lambda \alpha ́ \delta \imath \kappa \alpha$ ), $\sigma \kappa v \lambda \alpha \alpha \rho \alpha \pi \alpha \varsigma$ (racist in-

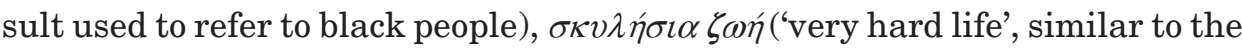
English dog's life), etc.

This attitude towards the animal has remained unchanged till nowadays. On the one hand, we are faced with an explosion of animal loving (which is, of course, a more modern type of behaviour since the relationship human-animal has moved into the area of ideology and the idea of animal protection has become a trend). This attitude has been translated into the founding of animal loving organizations, shops with dog accessories, special shelters for dogs, vets and specialist magazines. On the other hand, however, we have witnessed dog poisoning and torture, experiments on dogs, the abandonment and killing of dogs in the streets, dog fights, and so on.

\section{Dog sacrifices in ancient Greece and Rome as two cases of the wider Indo-European practice: similarities to the Modern Greek custom (kynomartyrion)}

Dog sacrifices, in the Indo-European and, in particular, the ancient Greek and Roman culture, can be mainly separated into two categories; that of the $c a$ thartic and that of the fertile. In what follows we will discuss them since, as will be shown in a later section of this article, they can be traced in the modern version of the ritual, namely, the dog torture (kynomartyrion).

The first reference to a dog sacrifice in a Greek text appears in the Iliad: Achilles, honouring the dead Patroclus, throws two headless dogs (among other things) on the fire (rhapsody $\Psi$, verses 173-174). Plutarch (2000) mentions (Vitae Parallelae, Pकuv́ros (Romulus), 21) that the dog is widely used by the

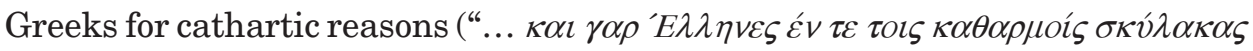

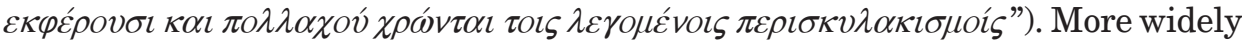
known, as we have said, were dog sacrifices held in honour of Hecate (and Artemis = Diana). In fact, this goddess was given the name $\kappa v v o \sigma \varphi \alpha \gamma \eta$ ' ('dog slaughterer'). Let us mention at this point the case of the island of Samothraki,

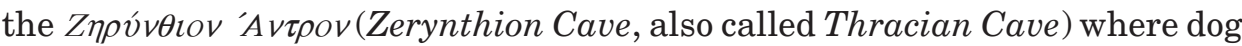
sacrifices took place in honour of the goddess (Decharme 1959: 154; Kourtidis 1938-39: 95). On the island of Aegina the inhabitants also honoured the goddess twice a year with dog sacrifices, the tradition being supposedly introduced by Orpheus. 
These goddesses were of Thracian origin, perhaps Carian. They were adopted by the Orphics (Fauth 2006: 19-25), later linked to those of Attis, Kyveli, Isis and other chthonic deities and rituals of a mystico-magic character (Decharme 1959: 154). Hecate (and Diana) was considered a moon deity, as has been reported in Suidae Lexicon and the Homeric Hymn to Demeter ('Y $\mu \nu \circ \varsigma \varepsilon l \varsigma \tau \eta \nu$ $\Delta \eta \mu \eta \tau \rho \alpha$ ), 6th century BC, verses 51-53 (see Allen et. al. 1963). The same view is shared by many recent scholars (e.g., see Johnston 1990: 29-38; Eliade 1981). In some representations, the goddess is depicted carrying a torch, and in other cases a key $(K \lambda \varepsilon \iota \delta o v \chi o \varsigma)$ and a snake, thereby pointing to her lunar origin. This is also made clear by her name (female of Ekatos, meaning someone shining at a long distance, far away in the sky). Even her representation on magic papyruses of later antiquity, as three-headed (with a head of a dog, a snake and a horse), is possibly related to her lunar character ${ }^{6}$ and also prob-

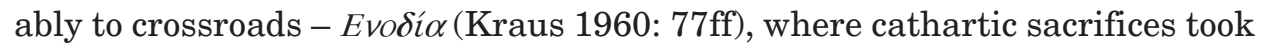
place and their remains ( $\kappa \alpha \theta \alpha \dot{\alpha} \rho \mu \alpha \tau \alpha, \kappa \alpha \theta \alpha ́ \rho \sigma \iota \alpha)$ were put next to her statues, ${ }^{7}$ so as to get rid of the spirits (Fauth 2006). This is why the moon was worshipped by them (Ragon 1981: 134) and was related to the dog, which was a demon of the underworld.

What has been stated regarding Hecate is also applicable to Artemis (Diana) after the 4th century BC as has been mentioned above. During this century (and later), of all her distinctive facets, the dominant one was her identity as goddess of the moon. Hecate gives way to Artemis (see Aeschylus 1910, Tragodiae, Supplices, verses 675-677), who is identified and, eventually, assimilated to her at the time of Theocritus (Brunel 1988: 30; Nouveau-Piobb 1961: 223241). The centre of Artemis' worship was Ephesus (in Asia Minor). In Thrace, she was identified with the Thracian goddess Vendis (BÉv $\delta \imath \delta \alpha$ ) (Decharme 1959: 154). It is noteworthy that Thrace and Asia Minor were areas where dog sacrifices were still taking place even in the 20th century. Artemis was a moon deity, too, with a plethora of symbolic emblems (the dog and the wolf among others). Many of these animals are mentioned as sacred victims in the sacri-

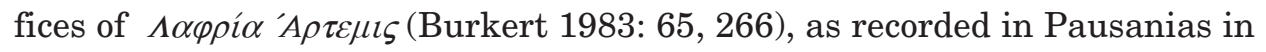

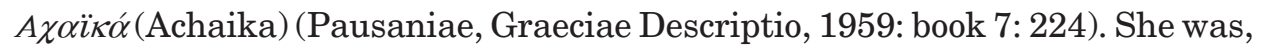
in other words, among others the protector goddess of rural nature, fauna (she

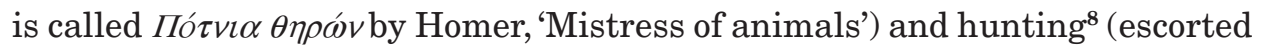
by dogs in her Kallimachus' hymn she begs her nymphs to take care of her dogs, verses 15-17). Thus, the goddess belongs to the general religious scheme of protectors of fauna and to that of the fertilizing goddess.

Dog sacrifices had a cathartic dimension in the purification rituals that took place before a battle or a military expedition (Nilsson 1906: 405-406). In 
many cases such ceremonies included the soldiers' parading between two halves of a severed dog. Plutarch mentions such examples in the army of Boeotia and Thebes (see Megas 1923: 509). The Persian king Xerxes, according to the ancient Greek historian Herodotus, during his campaign against Greece, made his troops pass between the two parts of a sacrificed human, which reminds us that the dog replaced human victims (Nilsson 1906: 405-406). In a wider IndoEuropean context, F. Blaive mentions a similar parade by Hittites between pieces of a human, a dog or other animal. Moreover, in India, during the Ashvamedha (the sacrifice of the horse) ceremony, a dog was sacrificed to protect and increase the number of valuable horses (Blaive 1995: 287).

In ancient Sparta, as reported in Pausanias (1959: 3, 14, 9), adolescents sacrificed puppies to Apollo and Ares (Mars) before a battle, because dogs were

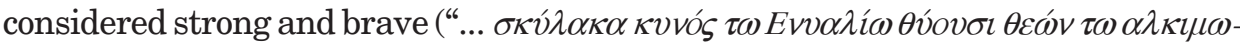

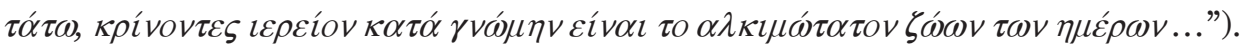
A sacrifice of a dog (being $\alpha \lambda \kappa \iota \mu \omega \tau \tau \tau \tau o v$, a 'very strong animal') to Ares is also mentioned in ancient Greek texts many times (Bodson 1978: 126; Kadletz 1976: 78-79), since the dogs had a reputation for strength and endurance in the history of wars (Kadletz 1976: 282-283).

Pliny reports a dog sacrifice during the Roman celebration of Genita Mana, who was the protector of children (Blaive 1995: 279), since the goddess was present at birth. Plutarch (1924: ch. 52: 142-143) records a similar case in Argos, where a dog was sacrificed to help a child's birth. We recall Hecate was related to the birth and salvation of Zeus, since she was considered one of the

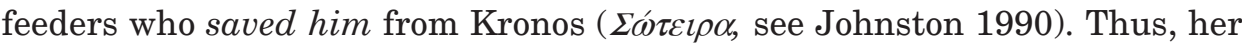
correlation and subsequent identification with the helpers of the women during birth, along with her sensitive attitude towards the Demeter's pain, who was desperately seeking Persephone (another option of her 'double' character), was successful. Furthermore, Artemis was divine - a protector of mar-

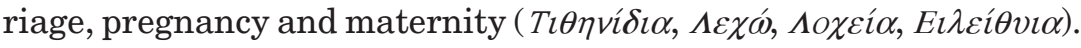

The connection of the death rituals with fertility is testified by hundreds of local examples in many nations. Even the murder of the sacred king or a king is a fertility ritual (Frazer 1994: 147; Burkert 1997: 116). In the same vein, the practice of dog sacrifices possesses the same dimension both in the GrecoRoman and possibly the wider Indo-European world. It is aimed quite clearly at securing a fertile year, good crops and other material goods.

To start, we will briefly refer, since they are well known, to three Roman celebrations and one ancient Greek one, to which Modern Greek dog sacrifices, as they are recorded over the 20th century, present quite astonishing similarities. 
1. The Luperkalia was a cathartic, rural and pastoral celebration of the Palatine Hill shepherds, near the mythical cave where Romulus and Remus were born, whose aim was to secure a successful year. This celebration was taking place every year on the 15th of February. According to Plutarch (Vitae Parallelae,

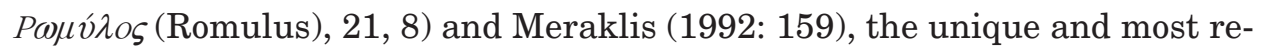
markable characteristic of this celebration was the dog sacrifice.

2. The annual celebration Robigalia, in the Via Claudia on the 25th of April (Blaive 1995: 279; Burriss 1935: 34-35). It was held to appease the god/goddess Robigo. ${ }^{9}$ In Pliny's view, the celebration was introduced by Numa in the eleventh year of his rule (Frazer 1931: book IV, 421). Ovid details this celebration in his poem Fasti (Frazer 1931: book IV). The priest prays to the goddess to save the crops from the terrible disease that carries her name. The procession of the faithful (Gebauer 2002), dressed in white, heads for her sacred grove, to offer to the flames the entrails of the sacrificed animals, a sheep and a female dog, as reward to their supernatural owner. The priest wishes the disease were transferred from the cultivated fields to the weapons of war (the well known motif of the transfer of the disease, see James Frazer (1994: 68ff) and Otto Weinreich (1969: 121ff)), giving, thus, to the description an anti-war element.

3. Augurium Canarium or Sacrum Canarium was an annual moveable Roman celebration, taking place in late April or early May, which is in fact quite close to the fixed celebration of Robigalia. It took place in Porta Catularia (Puppy's gate) of Rome, because it was there that "red bitches were sacrificed to appease the Dog-star, which is hostile to the corn, in order that the yellowing corn may reach maturity" (Frazer 1931: 422; Burriss 1935: 34-35). The aim of this ritual was to appease (by means of a dog sacrifice), the deadly star Sirius,

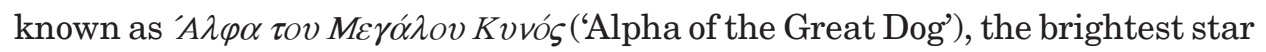
of all, which rises at dawn on 2 nd August. Its name indeed means 'hot' (Aristo-

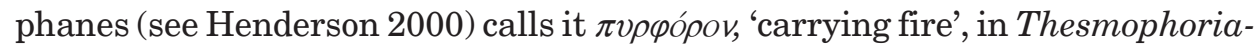
zouses, verse 1050) because its rising signalled the beginning of the so-called

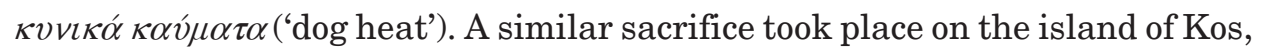
although the species of the sacrificed animal is not specified (Burkert 1983: 109-110). The dog sacrifice took place - just as in the case of the sacrifice conducted in Greece until very recently - for the protection of the crops, wheat in the case of Rome, sesame and agricultural production in Thrace, in other words, the main source that supported life in both societies. It is remarkable, although quite natural, that in both cases the sacrifice took place before the hot period began (Frazer 1931: 422). In Rome, the execution of the dog was 
earlier related to the belief that the priest was to take the omens from the dogs on the day of sacrifice before the new wheat seed grew; the universal anxiety over the possible destruction of growth because of summer drought. The period before the budding of the seed was late April or early May. In Modern Greek custom, the aim of which was appeasement, incl. rabies, dog sacrifice took place during the spring celebrations as described later in this study, which is another striking similarity to the ancient Greco-Roman practices.

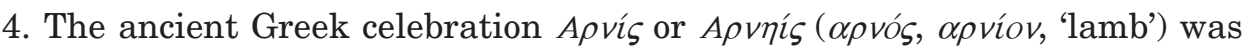
purificatory and expiatory. It was held by the inhabitants of Argos at the beginning of summer to pray for the increase of their flock. Its premises lie in the very old traditions of Argos regarding Apollo and Psamathi ( $\Psi \alpha \mu \alpha \dot{\alpha} \theta \eta)$ and their illegitimate offspring, Linos. This tradition is recorded in many ancient Greek

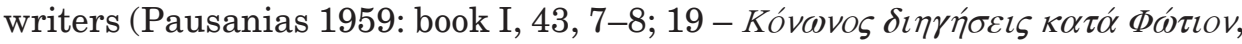
(Konon's narrations in Photio's words)). The month when Linos' celebration took place is called "the Month of the Lamb", as reported by Photios (" $\mu \eta \dot{v} \alpha \tau \varepsilon$

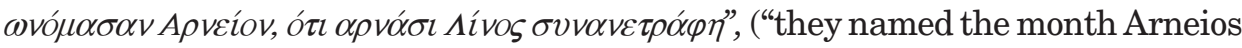
because Linos was brought up among lambs") (see Paulys Realencyclopädie der Classischen Altertumswissenschaft 1894: Vol. II1: 1203-1204). The same celebration is reported in Athenaeus (Athenaei Navcratitae Dipnosophistarum,

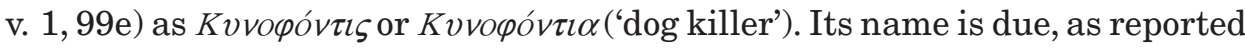
by Claudius Aelianus (1864: De Natura Animalibus, IB', 34) to the fact that the inhabitants of Argos, apart from the lamb sacrifices, also killed all dogs that

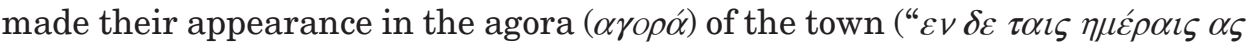

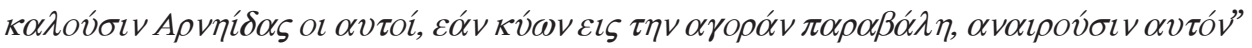
("if a dog made its appearance in the agora during the days of the month Arneios, it was killed"). The celebration took place during the period of the 'dog heat' ( $\kappa v \imath \kappa \alpha ́ \alpha \kappa v ́ \mu \alpha \tau \alpha)$, when dogs suffer from rabies, and is symbolized as a battle against the deadly heat caused by Sirius. The agora of Argos was under the

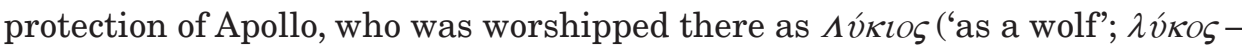
'wolf'). It is not at all coincidental that Sophocles calls this god 'wolf-killer' ( $\lambda$ ขкоктóvov), which is a hint regarding the killing of its cousins during that celebration (Burkert 1983: 108). Thus, this deed has important implications. If agora was the humanized public territory, the political area, the place of civilization, then the killer-dog, which had torn apart the baby Linos, is the bearer of the secular world, which stands beyond civilization. It therefore does not belong to it, and has to be put to death when it makes its appearance. The wolf in the folk consciousness is identified with the dog since both animals unquestionably have the same ancestor (Russell \& Russell 1978: 143ff). In the Lupercalia, for instance, a dog was sacrificed instead of a wolf, since it was an animal 
easier to find, given that it had long before been tamed and lived in great numbers in the rural communities. It was sacrificed in expiation to the demon - wolf-god (Lupercum- $\alpha \alpha v v^{\prime \mathbf{1 0}}$ ), in particular. He is the ancient wolf-headed god, the beast-headed beneficial for budding and fertility demon to whom dogs were offered for worship and appeasement. This is, of course, a typical case of totem worship, in which the concepts animal and deity are identical. ${ }^{11}$

However, in the Ovidian Fasti, it is clearly stated that "this dog is set on the altar, instead of the celestial dog and its name is the cause of its death" (see verse 942). The dog, whose name is identified with the celestial star, is considered the symbol of the dry heat of the star, so deadly to vegetation. It is therefore sacrificed in order for the humans to avoid the heat of Sirius and it is thus another form of homeopathic magic, similia similibus sanantur (Imellos 1972: 68-72). The victims need to resemble the one they replace in order to offer to the violence the required loot. This is a similarity which reaches absolute assimilation. The dog is a victim, and the destructive celestial star becomes the same by the analogy of name. We have here one more proof of the remarkable identifying function of names (Lévi-Strauss 1977: ch. 2, 6). The same applies to colours; heat (Sirius) has the colour of fire, so does the small female dog sacrificed in the Ovidian example. As we have said, the victim represents death and life, illness and health and sin and virtue, since the sacrifice expresses the ambiguity of the religious powers.

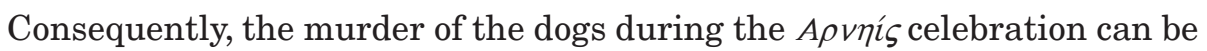
clearly interpreted, if we take into consideration that the handsome Linos was the personification of spring and budding vegetation which is likely to be destroyed by the heat brought by Sirius. Sirius therefore needs to be appeased in advance. This interpretation of the facet of dog sacrifice coincides notably closely with the folk interpretations of the custom in 20th century Greece which follow.

\section{THE VARIOUS FUNCTIONS OF THE MODERN GREEK CUSTOM OF KYNOMARTYRION (FERTILITY, CATHARTIC, ETC.)}

The Modern Greek spring dromena, an early form of theatre (Puchner 1989: 48), such as dog torture (kynomartyrion) fall within the wider cycle of rites of passage. They were performed at some turning point of the year, the passage from winter to spring, in particular. As such, they occurred at "dangerous, transitory moments of the year cycle". Their main goal was the rebirth of nature (fertility). In these rituals, by means of numerous symbolic overturns, 
the identification of the end with the beginning, the cyclical conception of time, the sense of perceptual repetition and the unity of the opposites were dramatized. The cycle of the year for the layman of the countryside was defined by two identical points, since essentially one first produced the other. Death (end) led to rebirth (beginning), the winter to the spring, the old to the new, thereby refuting time and giving the sense of eternity to the community (Nitsiakos 2003: 120ff; Sergis 2007: 19-23).

The cosmological sense of the rebirth of time and the return of vegetation is dramatized through the archaic myth of the annual death (and usually resurrection) of a god, or a vegetation demon or a person, usually young in age, girl or boy (for example Adonis, Persephone or Linos, in particular). This motif secures the eternal recycling of life. Death and life are identical; the first is considered fertile and subsumes the idea of resurrection (Kiourtsakis 1995: 84-85, 88, 91, 103-104, passim; Meraklis 1989: 251). In our case, we have the sacrifice of a small demon, a dog, which is sacrificed as an expiatory victim to the demon god. We have here one more transformation of the scapegoat. In the light of Wilhem Mannhardt's animistic theory about the battle of diseases, which suggests that the diseases are avoided or cured violently, the scapegoat (Frazer 1994: 126ff; Burkert 1997: 110), since it is a vegetarian spirit, must be whipped, expelled, put to death before it is reborn. Beating in folk culture, especially during carnivals, is one more action of body drama. The beaten subject, (the dog in our case), is ridiculed, humiliated and killed but, at the same time, purified and revitalized. In its turn, it purifies the collective body (Kiourtsakis 1995: 106-107). In other words, beating belongs to ambiguous actions that are both deadly and revitalizing at the same time. Life is unique but autonomous, as well. Consequently, it must accept death, or it carries death, in order to be eternal. We usually sacrifice to the deity our most precious belongings. This is probably the reason why the dog has always been the victim in such sacrifices. Its behaviour and intelligence were very close to those of humans, as we have stressed in a previous section of this study. The tamed animals which live in human homes, have a human element, according to Joseph de Maistre, and this is the reason why they have always been selected for sacrifice (Girard 1991: 14). These animals, due to their instincts and abilities reminded more the humans than their previous condition, that of impure and non-social being. ${ }^{12}$ In order to render the animal more conducive for sacrifice, it needs (inter alia, e.g., the animal offers itself voluntarily, see Imellos 1994: 344-375) to be assigned the most remarkable similarity to non sacrificial categories, that is, human beings (Roux 1998: 318).

In Soufli, for instance, on Monday, after the second week of the carnival period, the men of the village collected as many dogs as possible and held them 
still by means of a pitch-forked piece of wood. Then, one of them tied to the dogs' tails an object and released them to run around and make noise. This is often found in such rituals, intended to expel evil spirits. The tortured dog's dreadful howling in kynomartyrion, may consequently, have been considered a frightening sound, to be regarded in connection with the expulsion of demons (Politis 1904: Vol. 2: 1310-1314), since, during the carnival period, the underworld is on earth. Elves (kalikantzari), the sacred visitors of the Twelve-Day

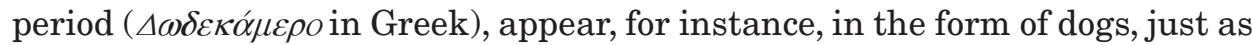
all demons and fairies in traditional magic (Benekos 1998: 35; Stewart 1991: 187-188). The great ruler - king of hell, Ariel, appears as a huge fiery dog, according to medieval tradition among dozens of peoples. The devil also takes the form of a black dog (Politis 1874: 474-475; Rudkin 1938; Brown 1958; Bayless 1970; Brown 1978; Trubshaw 2005). This superstition probably originates from the figure of the ancient guardian of Hades, Cerberus. Such a hypothesis is further supported by the fact that what matters in the kynomartyrion is not the death of the dog itself. Most probably, this animal is conceived as most appropriate for the expulsion of demons, who traditionally appear as dogs, such as those mentioned above. If this is the case, we can attribute a cathartic function to this custom as well. In Adrianopolis, in particular, the pursuit and capture of the dogs was performed by the followers of the Kopek Bey (dog master, the king of the carnival in Thrace) who, carrying wooden clubs and covered with black smoke dirt, attempted to catch the animals using specially constructed tools "to turn them upside down in order not to catch rabies in summer" (Kourtidis 1938-39: 93). This turning upside down of the animal, as has been remarked by K. Kourtidis, probably symbolizes its symbolic death. More specifically, possibly the aim is to make the animal touch the ground for some time (the earth being a chthonic deity, Mó $v \alpha \Gamma \eta$, 'Mother Earth'). She is mother of all creatures but also home of the dead, who, nonetheless, carries rebirth, the eternal recycling of life (see, e.g., Turner 1969: 161). Kourtidis describes the dogs as rising and running away, instead of being put to death. Is this variation of the kynomartyrion to be considered within the common motif of death-rebirth, the dying and reborn god mentioned earlier, met in dozens of Modern Greek dromena or is it a form of symbolic sacrifice, a remnant of older dog sacrifices aimed at promoting fertility? In this custom do we witness the passage from the sacrifice to its symbolism?

Another possible explanation of the custom relates to the special meaning the dog bears and the particular period of "Clean Monday". Those who wear masks during the carnival period are called $\Sigma \kappa v \lambda \alpha \rho \alpha i o r$ ('crowd of dogs'). At Perista in the area of Nafpaktos, for instance, they are fifteen in number. 
Among them figure the doctor, the priest, the policeman, the groom and the bride, the old man and the old woman, the bear, which are all common figures during carnival time (Romaios 1944-45: 97ff; Puchner 1989: 49, 113, 116, 118; Puchner 1977: 170, 193, 216, 238, 259). This presupposes the existence of dog-

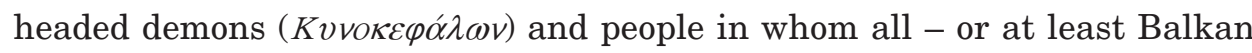
peoples - believed, from Slovenia to Asia Minor (see Kretzenbacher 1968 ; Klímová-Rychnová 1971; Politis 1904: Vol. 1: 206-207; Politis 1904: Vol. 2: 964965; Oikonomidis 1983; Oikonomidis 1987-88; Xygopoulos 1977-79; Chotzakoglou 2003). The traditions concerning this type of demons were probably formulated by Pseudokallisthenis' narrations in his popular book about Alexander the Great.

In addition to the above, reports from the villages of Roditis and Mesi in Aegiros (Western Thrace) clearly reveal that the aim of the custom was "to guarantee the safe growth of sesame" (Papatriantaphyllou 1993: 204; Varvounis 2004: 38), having thus a fertility function. To this same end, in Phanari of the same region, people used to hang cats (Varvounis 2004: 38, 67), animals closely parallel to dogs since they, too, are chthonic beings and very close to human beings (Sergis 2007: 40, 240, 264). These two species bear such similarities that they sometimes share common names, despite their enmity to each other in fairy tales. To provide but a few examples, in Samos, in Roditis, Phanari and

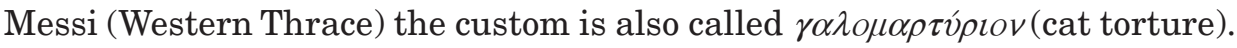

Another goal of the custom, similar to the related Roman and ancient Greek ceremonies described earlier, was the annual protection of dogs from rabies, as reported in Kourtidis and mentioned above (Kourtidis 1938-39: 93). The same interpretation is offered by Chr. Vakarelski in Bulgaria (1969: 320). Dogs are tortured to rid them of rabies, which is considered to nest in the animals' body throughout the year. Therefore in spring, before Sirius with its heat rises, these animals are in need of protection to prevent the disease.

Wolves and dogs share one more frightening characteristic. They are both carriers of rabies, which passes from the former to the latter and then to humans, decimated people in some early historical periods. W. M. S. Russell and C. Russell referring to R. H. A. Merlen's study on this disease, report that during the 1st century AD a great number of dogs were transferred to the Mediterranean countries from Northern Europe, causing the death of a large number of people who had been bitten by dogs and as a result, rabies was considered the most deadly disease in Europe from early Christian times onwards (Rozos 1968; Theodoridis 1984; Blancou 2003; King \& Fooks et al. 2004). This fact is further supported by Soranos in the 3rd century AD (quoted in Russell \& Russell 1978: 162-163). 
As has been pointed out so far, dog torture had similar functions with regard to the ancient dog sacrifice rituals discussed in the previous section. In what follows we will see how the performance of the custom was transformed into a folkloric, spectacular one with intense violent and sadistic behaviour on the part of humans in the places where it still took place after 1960.

\section{The changes that the custom underwent after the 1960s: from the sacrifice ritual to the spectacle}

After 1960, the custom lost its blood-sacrifice character in all Greek areas and became once and for all an entertaining spectacle, which had to be repeated every year for the reasons mentioned below. Certainly, it has always been a performance, in Erving Goffman's sense, being a conscious action on the part of its performers, and aiming at making an impact on the parties involved (Goffman 1959: 22). The goal of obtaining a good year and good crops was of utmost importance and the ceremony was certainly violent.

One question may be asked at this point. Why have researchers stressed so much the cruel human behaviour towards the dog, given the aforementioned ambiguous nature of the animal and the phenomenon of sacrifice ever since antiquity? It may be that violence was always a part of it in the archaic community, yet as a necessity for strict ritual formality. Violence has always been present, archaic or later traditional thought ritualized this, and it has occupied a position in the communal consciousness or sub-consciousness, different from a performance, such as the modern kynomartyrion, that is devoid of any sacred element. In other words, ever since ritual began to detach itself from its sacred element and turn into a common spectacle, violence is manifested in its primitive, original sense.

Rene Girard's interpretation of the phenomenon of ancient sacrifice comes to mind at this point. He discusses it as unanimous communal violence against the expiatory victim, whose aim is to put an end to the existing civil violence. He talks of the mimetic-desire which drives people to wish what others already wish. ${ }^{13}$ This mimetic desire leads, in its turn, to mimetic opposition and competitiveness among people, and, consequently, to a mimetic crisis within the community, which gradually leads to a climax of war. All real and imaginary dangers which threaten a community are assimilated to the danger that society faces. Girard called this imitation of the sacrificial crisis, which will confer unity on the community, the catharsis and the expulsion of intra-community violence. The ritual victim, the scapegoat (see Girard 1987) represents the expiatory victim. Since this victim represents all members of the community, its sacrificial substitution protects all its members from any violence in 
society. The sacrifice in Girard's view, "is the repetition of a first, impulsive hanging which set order in the community again" (Girard 1991: 160). He reminds us of Mircea Eliade's ideas (1999): An action becomes real, as long as it imitates or repeats an archetype (the motif of the eternal return). The passage from civil war to communal peace, the prohibition of discriminations, and the fundamental unanimity is what is requested by means of sacrifice. Homo religious acts and fulfils as homo necans, as W. Burkert also suggests (1983: 2, 4; see also Hamerton-Kelly 1987; Turner 1968).

In this vein, most modern folk performances, as dromena, have always had a striking appearance that is the chief element to attract the crowds even if the aim of the custom was self evident. After 1960, the rate of change to traditional ways of life in the Greek countryside accelerated rapidly. Among the reasons for these changes was decreasing apprehension over an uncertain future, increasing industrialisation of agricultural production and the concomitant decline in the worship of the fields, i.e. 'Feldkulte', according to W. Mannhardt. Until then the custom certainly retained its original meaning, to fertilize effectively and to obtain a good harvest and the protection of the crops. Modern farmers, however, do not believe anymore in the magical impact of sacrificed dogs, as is quite reasonable. They employ farming technology and the fertilizers. The custom survived, nonetheless, due to some other elements, which preserve it mostly as a spectacle, with its original meaning forgotten, or with new meanings attached to it derived directly from its new function as a spectacle. Let us also add folklorism to this, defined as the artificial revival of some old forms of life, especially those which can be represented as spectacle. Our age, which does not produce customs anymore, is fed by old recipes. In particular, the transformation into the spectacle discussed in this study custom was complemented with more elements which turned it exclusively into a hideous but spectacular performance. It survives as a picturesque spectacle. It entertains and amuses. It takes place only in order to preserve tradition. Young people who participate in it strengthen the ties of belonging (Cohen 1982; Sergis 2005: 45-46) to their community, show off their physical strength to the audience, and surpass, perhaps, personal anguish and conflict. Their opponents are now neither imaginary dangerous natural powers which envy their crops or spirits but a helpless dog that is tortured.

The custom has fallen into disuse in many Greek regions since 1930 due to the fact that it was regarded as brutal and sadistic. It was preserved in few Greek regions until 1970 or early 1980s and has disappeared since.

The aforementioned causes of the disappearance of the custom have mainly to do with its performers (the people of agriculture). Nonetheless, the main causes seem to have been extrinsic to the folk people who performed the cus- 
tom and related to two powerful social groups of pressure, namely, the Greek Orthodox Church and the animal rights organizations. In some villages of Thrace, for instance, we learn, it was banned by a newly-appointed priest (Varvounis 2004: 67). In Tychero (Evros), Rizomylos (Thessaly), and in island of Chios the custom was preserved but, due to opposition from animal lovers, animals have been replaced by dummies (Avdikos 1998: 197). In Chios, people used live animals up until 1982. An end was put to this by the unanimous vote of the general assembly of the local cultural organization. However, the celebration of dog torture was repeated in 1987 for the last time, being recorded and transmitted by Greek state television. This broadcast provoked an angry reaction on the part of the local environmental organization, which subsequently petitioned the local judge. The organizers were not punished for the reviving the custom although the relevant celebration had been prohibited since 1982 .

\section{CONCLUSION}

The custom of dog sacrifice in ancient Greece presents remarkably interesting similarities to the dog torture (kynomartyrion) in the 20th century Greece. What is also worth pointing out is that until the $1980 \mathrm{~s}$, when the custom completely disappeared, it mainly took place in areas where its ancient use had been testified, that is in Asia Minor (now West Turkey) and Thrace, within its wider territory (current European part of Turkey, South Eastern Bulgaria (previously Eastern Romylia) and Greek Western Thrace. After 1960, with the rapid technological development and the consequent rationalization that dominated the peasants' thought, the practitioners of the custom still recall its original function (fertility of the earth, cathartic functions, etc.) but the custom has nothing to do with its ancient ritual practice. Most of them do not consider it anymore a mediator for the fulfilment of their goals but regard it as a folkloristic performance that entertains them with its sadistic and violent elements. The latter characteristics were the cause of its falling in disuse in many areas as early as in 1930, and its disappearance in the 1980s. 


\section{NOTES}

1 I use the historical name assigned to our science by N. G. Politis (Politis 1909).

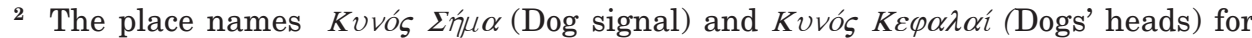
instance (Merlen 1971: 83). Romans loved dogs as well. There are abundant stories showing love and devotion to these animals in the literary folkloric texts of the Romans.

${ }^{3}$ References to the dog in the Christian and Muslim religions hold negative connotations, too. See for the former the Gospels of Matthew15, 26-27; Luke 16, 21; Mark 7, 27-28 and for the latter, see Woods 1959: 33.

${ }^{4}$ A different estimation, especially for the case of the sacrifice for Ares (Mars), is provided below.

5 They are depicted on coins of Epidaurus and on two carvings, treasured (numbers 173 and 174) in the National Archaeological Museum of Greece (see Bodson 1978: 86).

6 The three-faceted representation of the moon is a universal motif. Through the centuries the poets were playing more and more with allegorical interpretations of mythology and were greatly interested in interpretations having to do with stars. In this vein, Apollo was linked to the Sun, his sister Artemis (Diana) to the great night star, the Moon (see Brunel 1988: 130).

7 The first statue maker who presented her with three bodies was Alkamenes (Pausanias: II, 30, 2). He did that either because she was the ruler of three kingdoms of nature (according to Orphics) or because she represented the three phases of the moon (Stoics).

8 See her statue in the museum of the Vatican, where, escorted by her dogs, she holds a deer from its horns.

9 There are two contrasting views on the gender of the god/goddess. The older Roman historians and writers (Warro, Flaccus, Festus, Gellius) support the male nature of the god while Ovid, Columella and the Christian writers Tertylianus, Lactantius, Augustinus (inter alia) talk of a goddess.

${ }^{10}$ He was the father of Latinus (according to the Roman tradition), the mythical father of Romans. Some others, however, take him to be the king of Latio who was later identified with the goat-headed god Panas.

${ }^{11}$ See, for instance, (for the ancient Greeks and Egyptians) the example of Demetra horse, Panas - goat, Artemis - bear, Anubis - jackal or dog. All these examples of names recall the zoomorphic nature of the worship of god. With the anthropomorphism of gods that followed, which was a product of the evolution of the human thought, this identification was reduced but, nonetheless did not disappear. Centuries of human history passed before anthropomorphism replaced zoomorphism of gods entirely. 
12 The sacrificial code naturally demanded a male animal, not only because it was considered a less useful one for the household economy but, mainly, because (to the relevant male dominant prototype) it was more noble, stronger, bigger and untouched by the female impurity. The female sacrificial animal in some cases (e.g. in Robigalia because it was sacrificed to a goddess), although it violates the rule, was adjusted to other needs. It certainly required a young animal, thus perfect and healthy. The animal should also have colour, age and gender "relevant to the aimed outcomes". See H. Blau (1964: 109) where Indians used white dogs for their widely performed dog sacrifices, recorded since the 17 th and 18 th centuries. This choice had to do with the respect towards white animals which were believed to be symbols of purity, therefore appropriate to be dedicated to the Great Spirit.

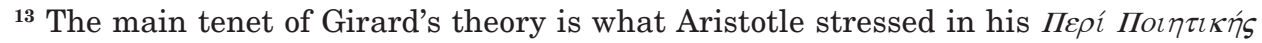

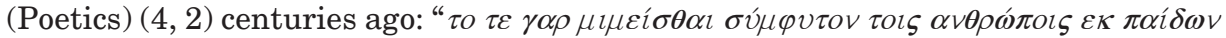
$\varepsilon \sigma \tau \hat{\imath}$ " (the ability/tendency to imitate is an inherent characteristic humans are born with).

\section{ANCIENT SOURCES}

Claudius Aelianus 1864. De Natura Animalibus, libri XVII. Ex recensione R. Hercheri. Lipsiae (Leipzig): B. G. Teubner.

Aeschylus = Aeschyli Tragodiae, (Supplices) 1910. Iterum edidit revisas H. Weil. Lipsiae (Leipzig): B. G. Teubner.

Henderson, Jeffrey 2000. Aristophanes: Birds, Lysistrata, Women at the Thesmophoria. Cambridge: Harvard University Press

Athenaus = Athenaei Naucratitae Dipnosophistarum 1985. Recensuit G. Kaibel, 1985, Stutgardiae: B. G. Teubner.

Allen, T. W. \& Halliday, W. R. \& Sikes, E. E. (eds.) 1963. The Homeric Hymns. Amsterdam: Oxford University Press.

Allen, T. W. (ed.) 1931. Homeri Ilias. Londini et Novi Eboraci.

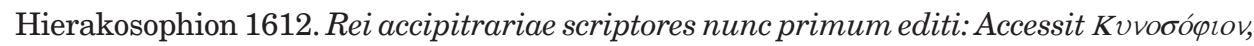
liber de cura canum ex bibliotheca regia Medicea. Lutetia: Exofficiana Nivelliana.

Homeri Odyssea 1889. Recensuit Arthurus Ludwich. Lipsiae (Leipzig): B. G. Teubner.

Lucanus, Marcus Annaeus s.a. De bello civili, libri decem. G. Steinharti aliorum copiis edidit Carolus Hosius, Lipsiae (Leipzig): B. G. Teubner.

Pausanias 1959 = Pausaniae Graeciae Descriptio. Recensuit Fr. Spiro. Stutgardiae: B. G. Teubner.

Burnet, Ioannes (reviewer) 1902. Platonis Opera. Londini et Novi Eboraci: e typographeo Clarendoniano.

Plutarch 1924 = The Roman Questions of Plutarch. Ed. by H. J. Rose. Oxford: Clarendon Press.

Plutarch 1947 = Plutarque, Sur la dispatition des oracles 1947. Ed. by R. Flacelière. Paris: Société d'Édition Les Belles Lettres.

Plutarch 2000. Vitae Parallelae. Ed. by Hans Gärtner. Monachii: Saur.

Suidae Lexicon 1931. Ed. by Ada Adler. Lipsiae: typis B. G. Teubneri. 


\section{REFERENCES}

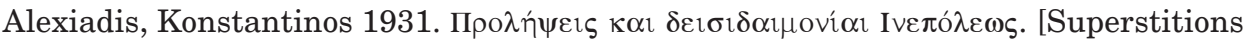

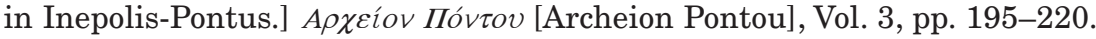

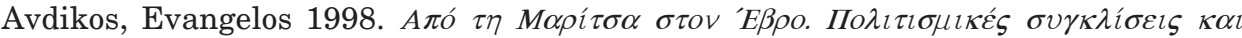

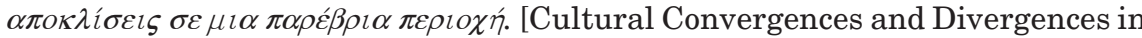
an Area Close to Evros.] Alexandroupolis: Polykentro of Tyhero Municipality.

Bayless, Raymond 1970. Animal Ghosts. New York: University Books.

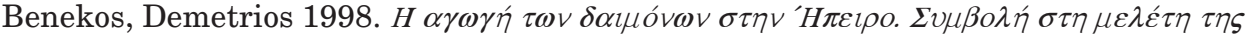

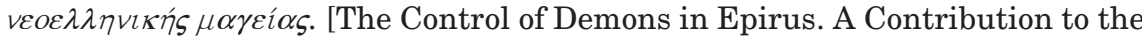
Study of Modern Greek Magic.] Ioannina.

Blaive, Frederic 1995. Le Rituel Romain des Robigalia et le Sacrifice du Chien dans le Monde Indoeuropéen. Latomus, Vol. 54, pp. 279-289.

Blancou, Jean 2003. History of the Surveillance and Control of Transmissible Animal Diseases. Paris: Office International des Epizooties.

Blau, Harold 1964. The Iroquois White Dog Sacrifice: Its Evolution and Symbolism. Ethnohistory, Vol. 11, No. 2, pp. 97-119.

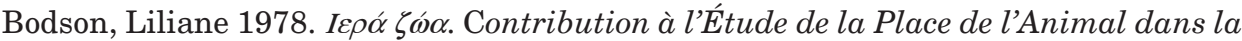
Religion Grecque Ancienne. Bruxelles: Académie Royale de Belgique-Palais des Académies.

Brown, Theo 1958. The Black Dog. Folklore, Vol. 69, pp. 175-192.

Brown, Theo 1978. The Black Dog in English Folklore. In: J. R. Porter \& W. M. S. Russell (eds.), Animals in Folklore. Mistletoe Series. Ipswich: D. S. Brewer Ltd and Rowman \& Littlefield for the Folklore Society, pp.45-58.

Brunel, Pierre (ed.) 1988. Companion to Literary Myths, Heroes and Archetypes. New York: Routledge.

Burkert, Walter 1983. Homo Necans: the Anthropology of Ancient Greek Sacrificial Ritual and Myth. Transl. by P. Bing. Berkeley: University of California Press.

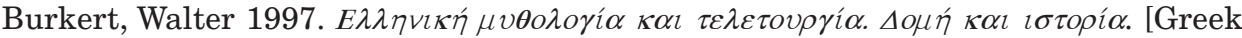
Mythology and Ritual. Structure and History.] Athens: Cultural Foundation of the National Bank of Greece.

Burriss, Eli Edward 1935. The Place of the Dog in Superstition as revealed in Latin Literature. Classical Philology, Vol. 30, pp. 32-42.

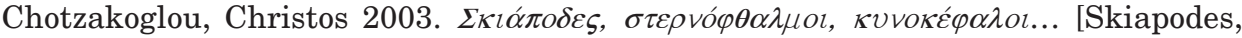
Sternophthalmoi, dog-headed...] Nicosia: Museum of the Holy Monastery of Kykkos.

Cohen, Anthony (ed.) 1982. Belonging: Identity and Social Organisation in British Rural Cultures. Manchester: Mahnchester University Press.

Crockford, Susan Janet (ed.) 2000. Dogs through Time: An Archaeological Perspective. Proccedings of the 1st ICAZ Symposium on the History of the Domestic Dog. Oxford: Archaeopress.

Cumont, Franz 1949. Lvx Perpetva. Paris: Librairie Orientaliste Paul Geuthner.

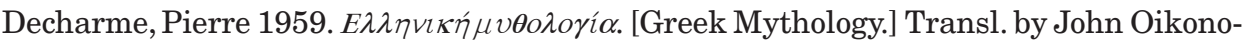
midis. Athens: Parthenon. 


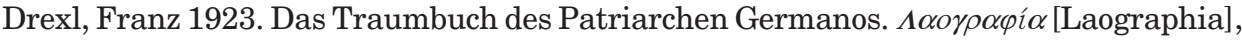
Vol. 7, pp. 347-375.

Drexl, Franz 1925. Das Anonyme Traumbuch des cod. Paris Gr. 2511. $\Lambda \alpha o \gamma \rho \alpha \varphi i ́ \alpha$ [Laographia], Vol. 8, pp. 428-448.

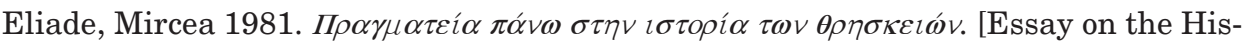
tory of the Religions.] Athens: Chatzinikolis.

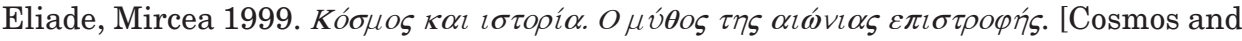
History. The Myth of the Eternal Return.] Transl. by Stratis Psaltou, Athens: Ellinika Grammata.

Fauth, Wolfgang 2006. Hecate Polymorphos, Wesensvarianten einer Antiken Gottheit: Zwischen Frühgriechischer Theogonie und Spätantiken Synkretismus, Hamburg: Verlang Dr. Konač.

Franco, Cristiana 2003. Senza Ritegno: Il Cane e la Donna nell' Immaginario de la Graecia Antica. Bologna: il Mulino.

Frazer, James George 1931. Fasti by Ovid. Transl. into English by J. G. Frazer. London: W. Heinemann \& New York: G. P. Putnam.

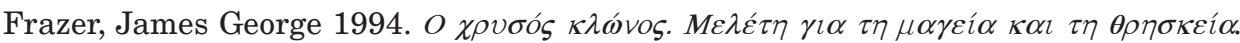
[The golden Bough. A Study on Magic and Religion.] Vol. $\Delta^{\prime}$. Athens: Ekati.

Gebauer, Jörg 2002. Pompe und Thysia: Attische Tieropferdarstellungen auf schwarzund rotfigurigen Vasen. Münster: Ugarit-Verlag.

Geffcken, Johannes 1978. The Last Days of Greco-Roman Paganism. Amsterdam \& New York: North-Holland Publishing Company.

Gilhus, Ingvild Sælid 2006. Animals, Gods and Humans: Changing Attitudes to Animals in Greek, Roman and Early Christian Thought. London \& New York: Routledge.

Girard, René 1987. Generative Scapegoating. In: R. G. Hamerton-Kelly (ed.) Violent Origins: Walter Burkert, René Girard, and Jonathan Z. Smith on Ritual Killing and Cultural Formation. Stanford CA: Stanford University Press, pp. 73-105.

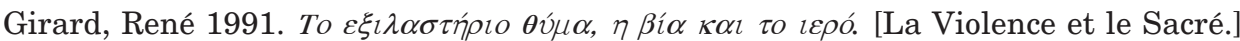
Transl. by K. Papageorgis, Athens: Exantas.

Godwin, Joscelyn 1981. Mystery Religions in the Ancient World, London: Thames \& Hudson.

Goffman, Erving 1959. The Presentation of Self in Every Day Life. New York: Anchor Books Doubleday.

Gourévitch, D. 1968. Le Chien, de la Thérapeutique Populaire aux Cultes Sanitaires. In: Mélanges d'Archéologie et d'Histoire de l'École Française de Rome, Vol. 80, pp. 247-281.

Green, Peter 1990. Alexander to Actium. The Historical Evolution of the Hellenistic Age. Berkeley: University of California Press.

Hamerton-Kelly Robert G. (ed.) 1987. Violent Origins: Walter Burkert, René Girard, and Jonathan Z. Smith on Ritual Killing and Cultural Formation. Stanford CA: Stanford University Press.

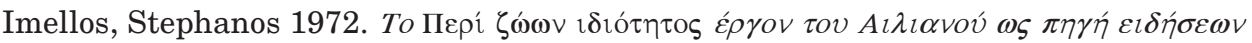

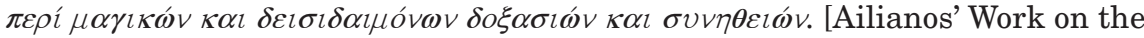
Qualities of Animals: A Source of Magical and Superstitious Beliefs.] Athens.

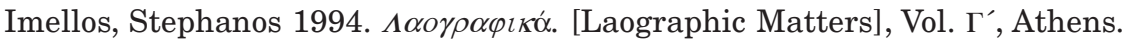


Johnston, Sarah Iles 1990. Hekate Soteira. A Study of Hekate's Roles in the Chaldean Oracles and Related Literature. Atlanta: Scholars Press.

Kadletz, Edward 1976. Animal Sacrifice in Greek and Roman Religion. Diss. University of Washington (University Microfilms). Washington: Ann Arbor.

King, A. A. \& Fooks, A. R. \& Aubert, M. \& Wanterel, A. I. (eds.) 2004. Historical Perspective of Rabies in Europe and the Mediterranean Basin. Paris: O.I.E.

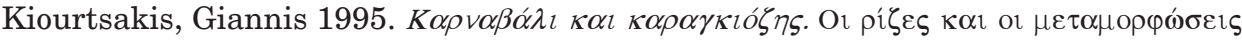

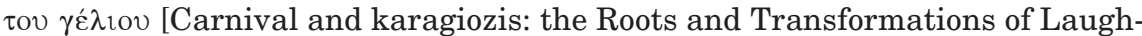
ter.] Athens: Kedros.

Klímová-Rychnová, Dagmar 1971. Zum Problem der Bundsköpsigen in der Volksüberlieserung. Zeitschrift für Volkskunde, Vol. 67, No. 1, pp. 95-110.

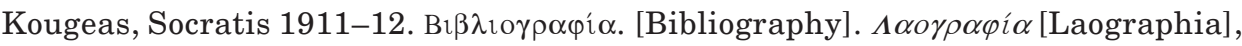
Vol. 3, pp. 298-299.

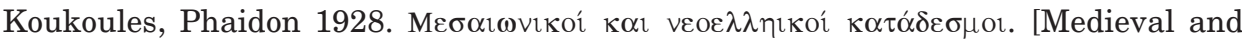

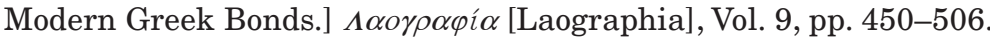

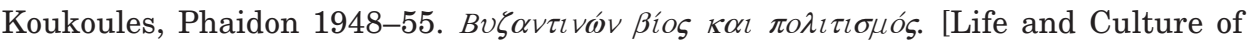
Byzantines.] Vol. 1-6. Athens: Institute Francais d'Athènes.

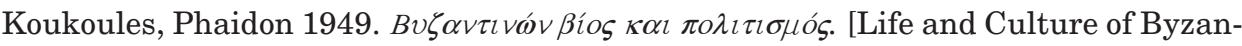
tines.] Vol. 3. Athens: Institute Francais d'Athènes.

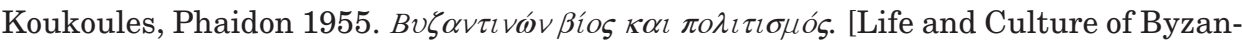
tines.] Vol. 6. Athens: Institute Francais d'Athènes.

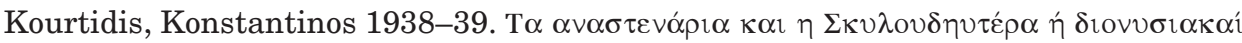

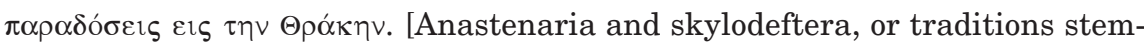

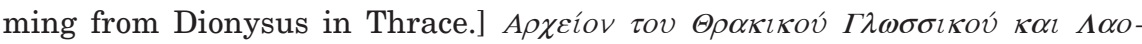

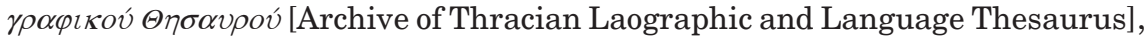
Vol. 5, pp. 90-95.

Kraus, Theodor 1960. Hekate. Studien zu Wesen und Bild der Gottin in Kleinasien und Griechenland. Heidelberg: Carl Winter, Universitatsverlag

Kretzenbacher, Leopold 1968. Kynokephale Dämonen Südosteuropäischer Volksdichtung: vergleichende Studien zu Mythen, Sagen, Maskenbrauchen um Kynokephaloi, Werwolfe und südslawische Pesoglavci. München: R. Trofenik.

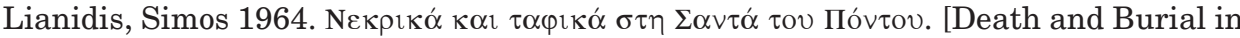

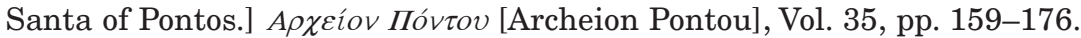

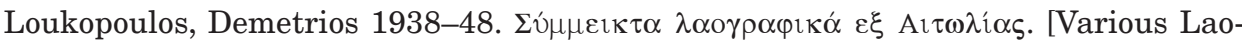

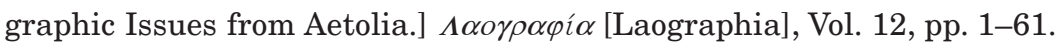

Mainoldi, Carla 1984. L'Image du Loup et du Chien dans la Grèce Ancienne: d'Homère à Platon. Paris: Éditions Ophrys.

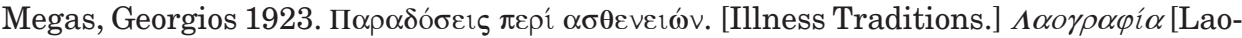
graphia], Vol. 7, pp. 465-520.

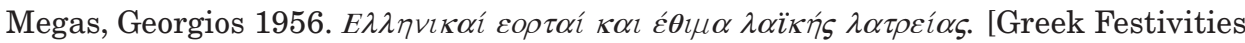
and Customs of Folk Worship.] Athens: Typographeion of Sotirios Spyropoulos.

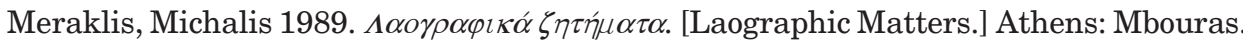

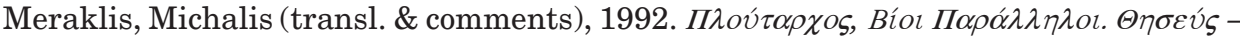

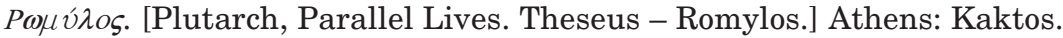

Merlen, Rene Henry Albert 1971. De canibus: Dog and Hound in Antiquity. London: J. A. Allen. 
Nilsson, Martin 1906. Griechischen Feste von Religiöser Beteutung: mit Ausschluss der Attischen, Leipzig: B. G. Teubner.

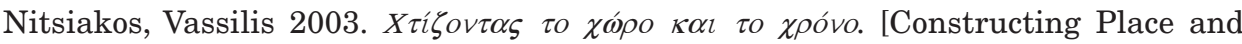
Time.] Athens: Odysseas.

Nouveau-Piobb, Maurice Francis 1961. Hécate. La déesse magique des âmes. Paris: Omnium littéraire.

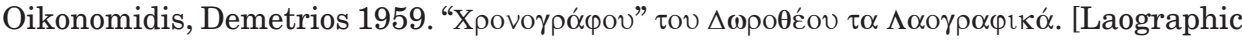

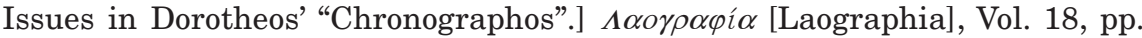
113-243.

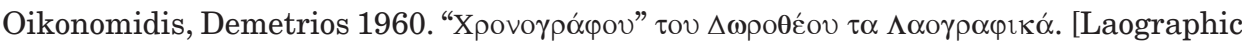
Issues in Dorotheos' "Chronographos".] $\Lambda \alpha o \gamma \rho \alpha \varphi i \alpha$ [Laographia], Vol. 19, pp. 395.

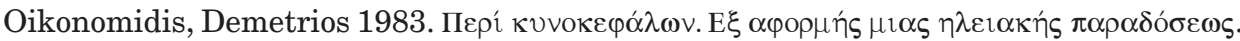
[On Dog-headed People, based on a Tradition from Heleia, Peloponnese.]

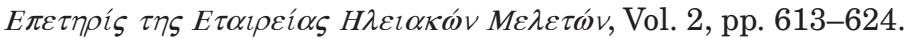

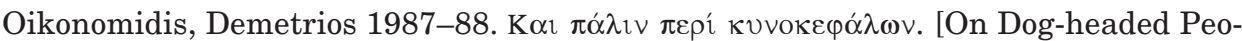

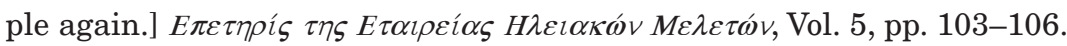

Oxford Dictionary of Byzantium 1991. New York: Oxford University Press.

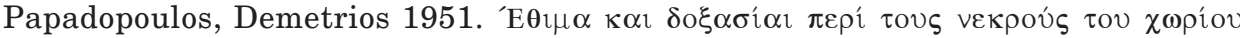
$\Sigma \tau \alpha v \rho i ́ v$. [Customs and beliefs about the dead in the village of Stavrin, Pontus.]

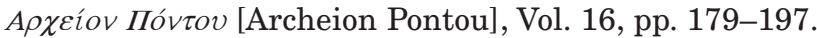

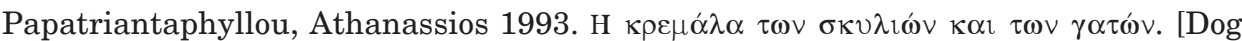
and Cat Hanging.] $\Theta \rho \alpha \kappa \imath \kappa \alpha ́$, Vol. 8, pp. 203-205.

Parker, Robert 1983. Miasma. Pollution and Purification in Early Greek Religion. Oxford: Clarendon Press.

Paulys Realencyclopädie der Classischen Altertumswissenschaft 1894. Neue Bearbeitung, unter Mitwirkung zahlreicher Fachgenossen herausgegeben von Georg Wissova. Stuttgart: J. B. Metzler.

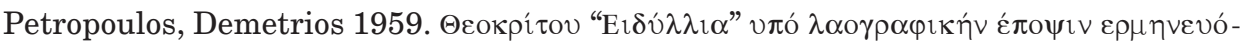
$\mu \varepsilon \vee \alpha$. [Theocritus' Eidyllia, Interpreted from a Laographic Perspective.] $\Lambda \alpha O$ -

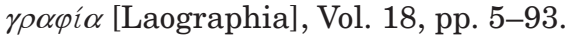

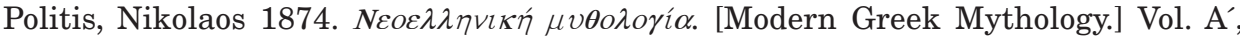
part B'. Athens.

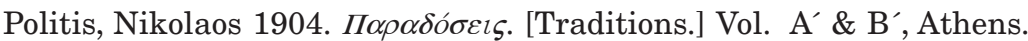

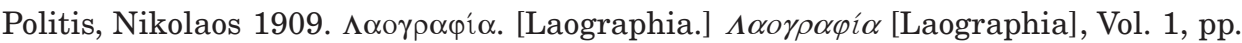
$3-18$.

Puchner, Walter 1977. Brauchtumserscheinungen in Griechischen Jahreslauf. Wien: Österreichisches Museum für Volkskunde.

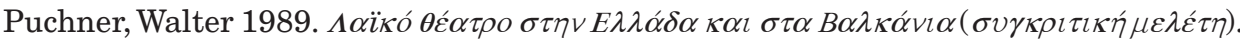
[Folk Theatre in Greece and the Balkan Countries: A Comparative Study.] Athens: Patakis.

Ragon, Michel 1981. L'Espace de la Mort. Essai sur l'Architecture, la Decoration et l'Urbanisme Funeraire. Paris: Albin Michel.

Ramm, Ben 2005. Barking up the Wrong Tree? The Significance of the Chienet in Old French Romance. Parergon, Vol. 22, No. 1, pp. 47-69. 


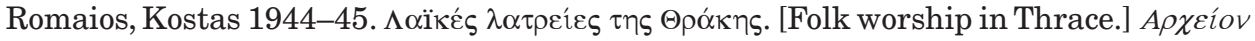

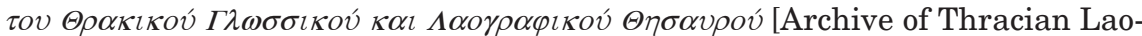
graphic and Language Thesaurus], Vol. 11, pp. 1-130.

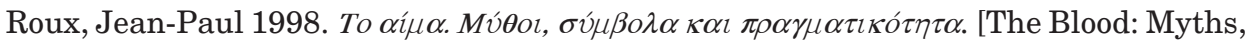
Symbols and Reality.] Transl. by Anda Klambatsea: Athens: Nea Synora Livanis.

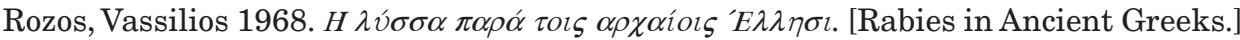
$\mathrm{PHD}$ dissertation. Athens.

Rudkin, Ethel H. 1938. The Black Dog. Folklore, Vol. 49, pp. 111-131.

Russell, William Moy S. \& Russell, Claire 1978. The Social Biology of Werewolves. In: J. R. Porter \& W. M. S. Russell (eds.) Animals in Folklore. Ipswich: D.S. Brewer and Rowman \& Littlefield for the Folklore Society, pp. 143-182.

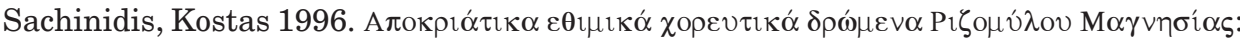

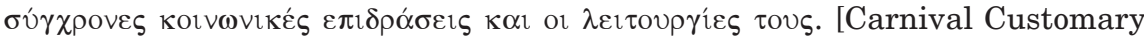
Dance Dromena in Ryzomilos of Magnesia: Modern Social Influences and their

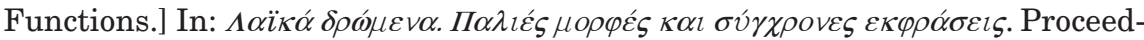
ings of the Conference, Komotini 25-27 November 1994. Athens: Ministry of Culture - Department of Folk Culture.

Scholz, Herbert 1937. Der Hund in der Griechisch-Römischen Magie und Religion. Disser. Berlin.

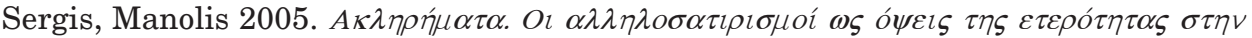

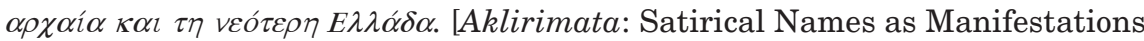
of Dissimilarity in Ancient and Modern Greece.] Athens: Antonis Anagnostou.

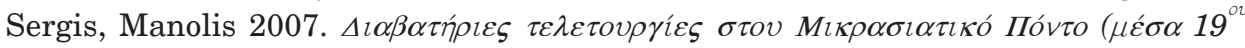

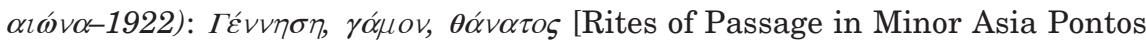
(mid 19th c.-1922). Birth, Marriage, Death.] Athens: Herodotos.

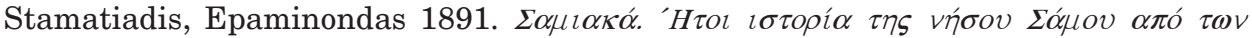

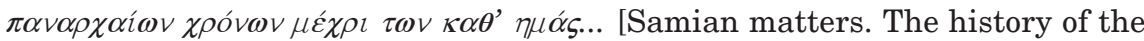
island of Samos since the ancient times...] Vol. 5, Samos.

Stewart, Charles 1991. Demons and the Devil. Moral Imagination in Modern Greek Culture. Princeton: Princeton University Press.

Lévi-Strauss, Claude 1977. H ó $\gamma \imath \_\alpha \kappa \varepsilon ́ \psi \eta$. [The Wild Thought.] Transl. by Marina Loe, Athens: Papazisis.

Theodoridis, James 1984. Rabies in Byzantine Medicine. Dumbarton Oaks Papers, Vol. 38, pp. $149-158$.

Toynbee, Jocelyn M. C. 1973. Animals in Roman Life and Art. London \& Southhampton: Thames \& Hudson.

Trubshaw, Bob (ed.) 2005. Explore phantom Black Dogs. Wymeswold: Published by Explore Books, an imprint of Heart of Albion Press.

Turner, Victor 1968. The Drums of Affliction, Oxford.

Turner, Victor 1969. The Ritual Process. Structure and Antistructure. London: Routledge \& K. Paul.

Vakarelski, Christo 1969. Bulgarische Volkskunde. Berlin: Walter De Gruyter.

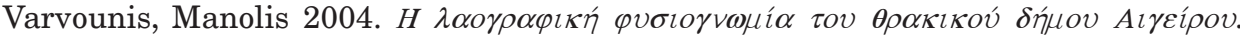
[The Laographic Physiognomy of the Thracian Municipality of Aigeiros.] Komotini: Municipality of Aigeiros. 


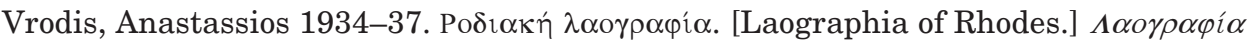
[Laographia], Vol. 11, pp. 532-594.

Weinreich, Otto 1969. Antike Heilungswunder. Untersuchungen zum Wunderglauben der Griechen und Römer. Giessen: de Gruyter.

Woods, Barbara Allen 1954. The Devil in Dog Form. Western Folklore, Vol. 13, No. 4, pp. 229-235.

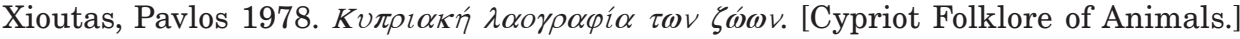
Nicosia: Dimosievmata tou Kentrou Epistimonikon Erevnon, no VI.

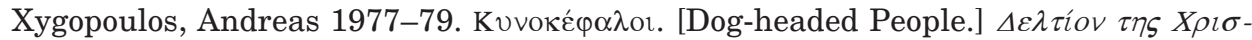

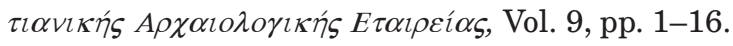

